\title{
Stimulating Action of Chlordimeform and Desmethylchlordimeform on Motor Discharges of Armyworm, Leucania separata WALKER (Lepidoptera: Noctuidae)
}

\author{
Hitoshi Watanabe and Jun-ichi Fukami \\ Laboratory of Insect Toxicology, The Institute of Physical and Chemical Research, \\ Wako, Saitama 351, Japan
}

(Received January 28, 1977)

\begin{abstract}
Behavioral and neural excitation of armyworm moths was immediately produced by the injection of each of chlordimeform (CDF; $10 \mu \mathrm{g} / \mathrm{moth}$ ) and desmethylchlordimeform (DMCDF; $10 \mu \mathrm{g} /$ moth), $N$-formyl-4-chloro-o-toluidine (FCT), and 4chloro-o-toluidine $(\mathrm{CT})$, which are less toxic insect and mammal metabolites of $\mathrm{CDF}$, did not produce any out-standing effect on motor discharges of armyworm moths. Regarding CDF and its metabolites, a correlation existed between their stimulating action on motor discharges and their insecticidal potency. The disturbance of larval feeding activities was clearly demonstrated in silkworm larvae treated with $\mathrm{CDF}$ or DMCDF, and it may result from the excessive neural excitation induced by the drugs. MAO-specific inhibitors, iproniazid, niaramid, and tranylcypromine, did not have any out-standing effect on motor discharges and their insecticidal potency were quite low.
\end{abstract}

\section{INTRODUCTION}

The mode of action of chlordimeform (CDF), $N$-(4-chloro-o-tolyl)- $N^{\prime}, N^{\prime}$-dimethylformamidine, was discussed in several reports and some interesting biochemical findings, i.e. inhibition of oxidative phosphorylation and stimulation of ATPase in the cockroach mitochondria, ${ }^{1)}$ inhibition of the synthesis of DNA, RNA, and proteins, ${ }^{2}$ and inhibition of monoamine oxidase (MAO) of the mammalian liver, ${ }^{3,4)}$ were made.

Regarding the physiological aspects, CDF caused noncompetitive suppression of acetylcholine (ACh)-induced contraction of rectus abdominis muscle of the frog and additionally caused a slow contraction at higher concentrations. ${ }^{5)}$ Furthermore, it was showed that block of neuromuscular transmission in the sciatic nerve-sartorius muscle of frog by CDF is due primarily to the depression of end plate sensitivity to the transmitter. ${ }^{6)}$ In cockroaches, the nervous hyperactivity characterized by the short volley of action potentials was evoked when the CNS was exposed to the saline containing CDF. And in this case, CDF did not block the synaptic transmssion. ${ }^{7)}$

In this report, the diverse actions of CDF found in frog nerve-muscle systems were further examined with the intoxicated moth, Leucania separata, by the electromyogramic observations. Effects of the metabolites of $\mathrm{CDF}^{8,9)}$ on motor discharges of armyworm were similarly analyzed from the correlation with their insecticidal potency.

In an attempt to examine the correlation between the MAD inhibition and insecticidal potency, three MAO-specific inhibitors, iproniazid, niaramid, and tranylcypromine, were examined.

\section{MATERIALS AND METHODS}

\section{Insects}

The adult males (1-3 days old) and larvae (3rd and 6th instar) of armyworm, Leucania 
separata, and the larvae of silkworm, Bombyx mori, at 3rd instar (Strain of Kinshu $\times$ Showa) were used as test insects. These were fed on the sweet corn leaves and mulbery leaves, respectively, and reared under the condition of $25 \pm 1{ }^{\circ} \mathrm{C}$ and relative humidity of $60 \pm 5 \%$.

\section{Chemicals}

Compounds tested were chlordimeform hydrochloride (CDF), $\quad N$-(4-chloro-o-tolyl) $-N^{\prime}$, $N^{\prime}$ - dimethylformamidine ; desmethylchlordimeform (DMCDF), $N-\left(4-\right.$ chloro-o-tolyl) $-N^{\prime}-$ methylformamidine; $N$-formyl-4-chloro-otoluidine (FCT); 4-chloro-o-toluidine (CT); niaramid, iproniazid phosphate, and tranylcypromine. Figure 1 shows their chemical structures. CDF and CT were obtained from Nihon Noyaku Co., Ltd., Tokyo, Japan, and they were recrystallized and redistillated to more than $98 \%$ purity level, respectively. DMCDF and FCT were supplied from M. Morikawa who synthesized both chemicals by the method described in elsewhere. ${ }^{10)}$ Purity of DMCDF and FCT were 99\%. Niaramid and tranylcypromine were purchased from the Sigma Chemical Co. Ltd., U.S.A. Iproniazid phosphate was purchased from the Wako

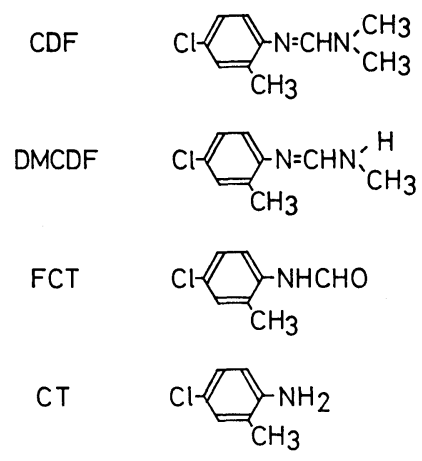

Iproniazid
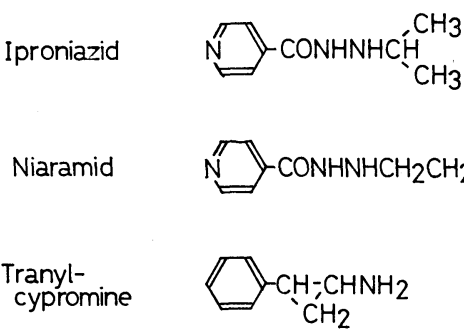

Fig. 1 Chemical structures of CDF, metabolites of CDF, and MAO-specific inhibitors.
Chemical Co. Ltd., Tokyo, Japan.

\section{Injection Tests}

Adult males (weighing about $200 \mathrm{mg} / \mathrm{moth}$ ) or 6th instar larvae (weighing $350-400 \mathrm{mg} /$ moth) of armyworm were injected with one (for adult) or five (for larva) microliter of the drug-containing saline solution from the dorsal region of abdomen by using microsyringe. Each of DMCDF, FCT, CT, niaramid, and tranylcypromine was dissolved in $50 \%$ ethanolsaline solution.

\section{Tests of Repellent Action}

Third instar larvae of armyworm and silkworm were used as test insects. Ten armyworm larvae were exposed to sweet corn leaves treated with drug solutions (concentration; $1000 \mathrm{ppm}$ ) in petri dishes. Ten silkworm larvae were similarly exposed to the mulbery leaves treated with the same concentration of drug solutions. At 2, 4, and $24 \mathrm{hr}$ after treatment, the symptoms of larvae and the feeding rate of leaves were checked.

\section{Recording of Motor Discharges}

The motor discharges were recorded from the metathoracic legs of the intact armyworm moths which was pinned ventral side up on a rubber platform. According to the method of Yamasaki and Narahashi, ${ }^{11}$ a pair of fine silver-wire electrode were used. One of which was in contact with the middle part of abdomen and the other was inserted in the femur of a metathoracic leg. For each dose of drug, more than five moths were examined. The muscle potentials were amplified and observed in a Universal Oscilloscope VC-7 (Nihon Koden Co. Ltd.).

\section{RESULTS}

1. Adulticidal Activity and Motor Discharges Toxicity of $\mathrm{CDF}$, metabolites of $\mathrm{CDF}$, and MAO inhibitors after injection to armyworm moths are shown in Table 1. Among the drugs tested, $\mathrm{CDF}$ was the most potent insecticidal compound against armyworm moths. The activity of DMCDF was rather weak, and those of FCT and CT were almost negligible. The MAO inhibitors, tranylcypromine showed slight insecticidal activity at the dose of 
Table 1 Mortality of armyworm moth injected with $\mathrm{CDF}$, its metabolites and MAO inhibitors.

\begin{tabular}{lccc}
\hline Compound & $\begin{array}{c}\text { Dose } \\
(\mu \mathrm{g} / \text { moth })\end{array}$ & $\begin{array}{c}\text { No. of } \\
\text { moth }\end{array}$ & $\begin{array}{c}\text { Mortality } \\
(\mathbf{2 4} \mathrm{hr})\end{array}$ \\
\hline $\mathrm{CDF}$ & 50 & 5 & 100 \\
& 10 & 20 & 100 \\
& 5 & 15 & 80 \\
DMCDF $^{\mathrm{a}}$ & 2.5 & 20 & 60 \\
& 50 & 5 & 80 \\
FCT $^{\mathrm{a}}$ & 10 & 10 & 50 \\
& 40 & 15 & 27 \\
CT $^{\mathrm{b}}$ & 10 & 20 & 10 \\
& 50 & 15 & 7 \\
Niaramid $^{\mathrm{a}}$ & 10 & 20 & 15 \\
& 100 & 14 & 14 \\
Iproniazid & 10 & 20 & 5 \\
Tranylcypromine $^{\mathrm{a}}$ & 100 & 14 & 29 \\
& 10 & 20 & 0 \\
50\% ethanol-saline & 10 & 10 & 40 \\
Saline & & 20 & 10 \\
& & 20 & 10 \\
\hline
\end{tabular}

${ }^{a}$ : Drug was dissolved in $50 \%$ ethanol-saline solution.

$25 \mu \mathrm{g} /$ moth. Other two MAO inhibitors did not show the distinct insecticidal activity.

Symptoms of the intoxicated moths induced by the different dose of CDF can be clearly distinguished. At doses more than $50 \mu \mathrm{g} /$ moth,

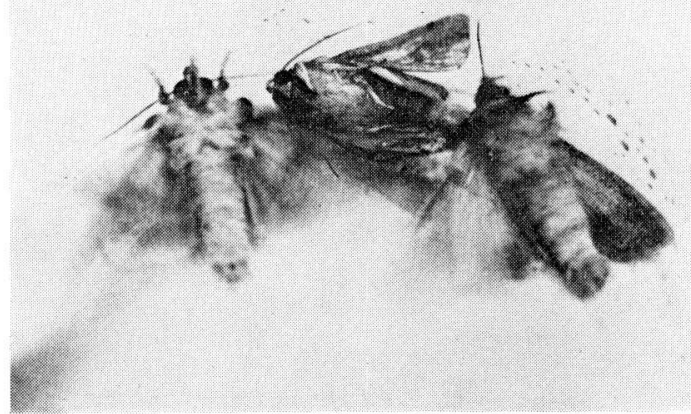

Fig. 2 Excitatory response of armyworm moths to $\mathrm{CDF} 4 \mathrm{hr}$ after injection. The moths with flapping wings on both sides are in the phase of excitation. The moth in the center was already in syncope.

both CDF and DMCDF caused syncope of the moth. And at doses less than $25 \mu \mathrm{g} /$ moth, each of $\mathrm{CDF}$ and DMCDF produced the continuous flapping flight (Fig. 2). In the case of $10 \mu \mathrm{g}$ injection of $\mathrm{CDF}$, this exciting response was continued for 4 to $6 \mathrm{hr}$. 5 to $8 \mathrm{hr}$ after injection, moths were severely debilitated and reached to the dead condition. Most of moths suffered the injection were died after 10 to $12 \mathrm{hr}$. FCT temporary immobilized the moths at the dose of $40 \mu \mathrm{g} / \mathrm{moth}$, but did not affect

\section{A}
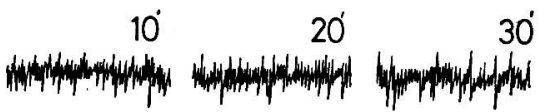

\section{$30^{\circ} \quad 60^{\circ}$}

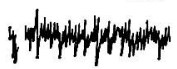

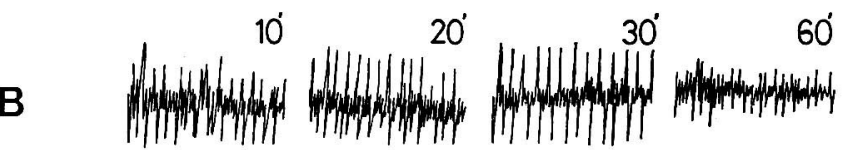
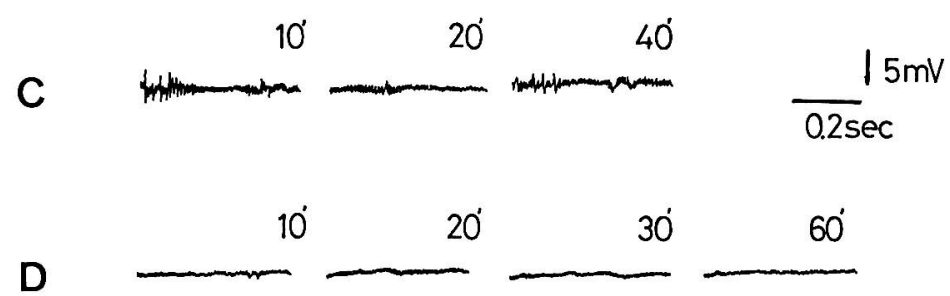

Fig. 3 Motor discharges recorded from the metathoracic leg of the adult male of armyworm injected with $\mathrm{CDF}$ and its metabolites.

A, CDF $10 \mu \mathrm{g} /$ moth; B, DMCDF $10 \mu \mathrm{g} /$ moth; C, FCT $10 \mu \mathrm{g} /$ moth; D, CT $10 \mu \mathrm{g} /$ moth. The numbers indicate the times after injection. 


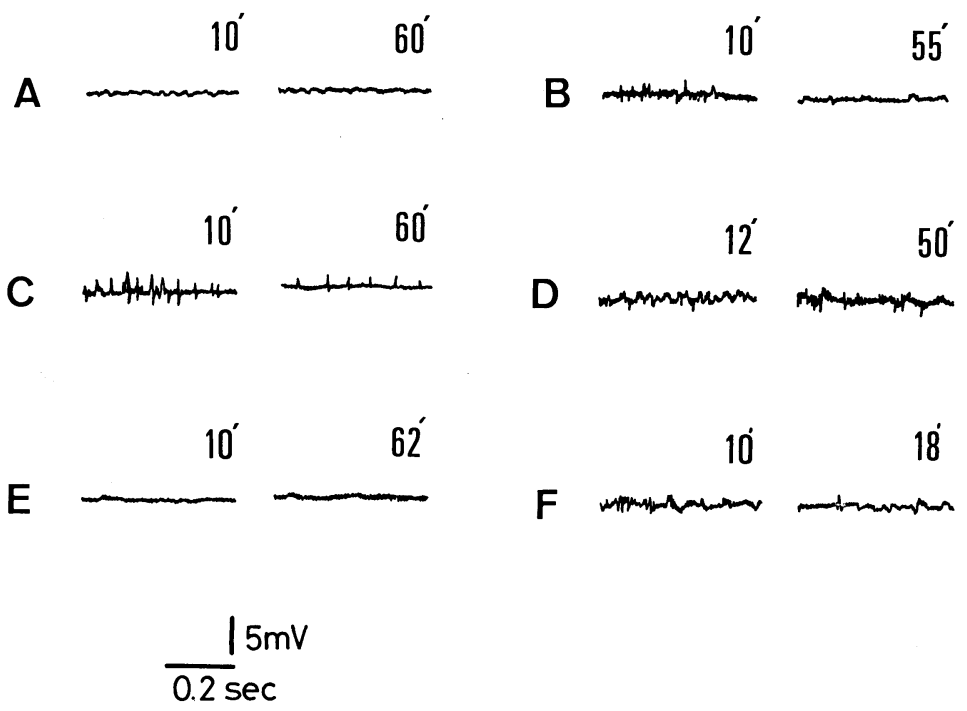

Fig. 4 Motor discharges recorded from the metathoracid leg of the adult male of armyworm injected with MAO-specific inhibitors.

A, niaramid $100 \mu \mathrm{g} /$ moth; B, tranylcypromine $25 \mu \mathrm{g} / \mathrm{moth}$; C, iproniazid $100 \mu \mathrm{g} /$ moth; D, iproniazid $10 \mu \mathrm{g} /$ moth; E, 50\% ethanol-saline solution; $\mathrm{F}$, saline. The numbers indicate the times after injection.

than at the dose of $10 \mu \mathrm{g} /$ moth. Tremore of the wings was observed in some moths which was injected with CT at the dose of $50 \mu \mathrm{g} / \mathrm{moth}$, but no effect was produced at the dose of $10 \mu \mathrm{g} /$ moth. A high dose $(100 \mu \mathrm{g} /$ moth $)$ of iproniazid caused the slight excitation. Although tranylcypromine had weak insecticidal activity, it neither caused the excitation nor other out-standing abnormalities.

The motor discharges recorded from the metathoracic leg of armyworm moths which was injected with each of $\mathrm{CDF}$, metabolites of $\mathrm{CDF}$, and MAO inhibitors are indicated in Figs. 3 and 4 . The frequency of motor discharges rapidly increased after injection of $\mathrm{CDF}$ and DMCDF (Figs. 3A and 3B) at the dose of $10 \mu \mathrm{g} / \mathrm{moth}$. Repetitive discharges induced by CDF continued for more than $4 \mathrm{hr}$. On 5 to $6 \mathrm{hr}$ after injection, the frequency of motor discharges was remarkably decreased accompanying with the prostration of the moths. On the contrary, less toxic compounds such as FCT (Fig. 3C), CT (Fig. 3D), niaramid (Fig. 4A), and tranylcypromine (Fig. 4B) did not produce any appreciable effect on motor discharges. Iproniazid slightly stimulated the motor dis- charges at the dose of $100 \mu \mathrm{g} /$ moth, but no effect was produced at the dose of $10 \mu \mathrm{g} /$ moth (Fig. 4C, 5D). The effect of the solvent, i.e. $50 \%$ ethanol-saline solution (Fig. $4 \mathrm{E}$ ) or saline solution (Fig. 4F), was examined, and no effect was observed.

\section{Larvicidal Activity}

Injection of CDF at the doses ranging 100$500 \mu \mathrm{g}$ per larva was followed by typical symptoms of the intoxication within five minutes, but did not produce the mortality of larvae. Symptoms included agony, uncoordination, and hyperactivity. 4 to $5 \mathrm{hr}$ after injection, most larvae were restored from CDF-poisoning. Similar symptoms were induced by the injection of DMCDF at the dose of $100 \mu \mathrm{g} /$ larva, but no mortality was produced. The larvae injection with $100 \mu \mathrm{g} /$ larva of FCT did not suffer from any noticeable effects. Different manners of larval response, which include immediate paralysis and death, were caused by the injection of $100 \mu \mathrm{g} /$ larva of CT. Iproniazid neither produced an abnormal response nor a mortality even at the dose of $500 \mu \mathrm{g} /$ larva. 


\section{Feeding Repellency}

Repellent action of CDF and its metabolites were distinctly demonstrated in the tests against silkworm larvae than in those against armyworm larvae. Both larvae of armyworm and silkworm revealed typical responses, i.e. rotation of heads and rapid crawling, on the leaves treated with each of CDF and DMCDF at 2 and $4 \mathrm{hr}$ after the exposures. Twentyfour hours later, the feeding activities of silkworm larvae were strikingly inhibited by $\mathrm{CDF}$ and MDCDF (Fig. 5). FCT, CT, and MAO inhibitors did not produce any standing effect on the behaviour of both of armyworm and silkworm and also could not induce the disturbance of their feeding activities. None of chemicals tested have caused the death of armyworm or silkworm at $24 \mathrm{hr}$ after treatment.

\section{DISCUSSION}

As indicated in Table 1, CDF shows a high degree of toxicity to armyworm adults. Armyworm and silkworm larvae, particularly at early stages, exhibited a slight disruption of their feeding activities when exposed to CDF. In this case, CDF could not cause the death of both species of larvae. As such disruption was characterized by exciting responses of the larvae, i.e. rotation of heads and rapid crawling, it may be able to speculate that the feeding disturbance in larvae is presumably due to excessive neural excitation. It has been also observed by Kono et al. that the accelerated probing frequency in $\mathrm{CDF}$-treated green rice leafhopper ${ }^{12)}$ was closely associated with initiation of repetitive motor discharge. ${ }^{13)}$ On the contrary, this neural excitation produced by CDF closely related to the insecticidal activity against armyworm adults since the severe prostration of moths resulted from the prolonged exciting behavior. Further application of $\mathrm{CDF}$ to the final state of armyworm learvae clearly demonstrated that the larvae have the extreme tolerance to $\mathrm{CDF}$-poisoning.

Yamamoto and Fukami found that CDF caused reversible blockade of neuromuscular transmission and repetitive discharges from single muscle fibres in larval waxmoth. ${ }^{14}$ In frog rectus, CDF at the concentration of $10^{-3} \mathrm{M}$ caused a slow contraction and noncompetitively inhibited the ACh-induced contraction at $10^{-4}-10^{-6} \mathrm{M}$. And the neuromuscular blockade by $\mathrm{CDF}$ was also found in sciatic nerve-sartorius muscle. From these observations, we notice



Fig. 5 A degree of feeding activity of silkworm larvae $24 \mathrm{hr}$ after the exposure to drug-treated mulbery leaf.

All of drugs were treated at the concentration of $1000 \mathrm{ppm}$. 
that $\mathrm{CDF}$ has the two different actions, i.e. stimulating action on nervous systems and blocking action of neuromuscular transmission in both of insects and frogs. This dual action of $\mathrm{CDF}$ possibly depends on the concentration of the drug.

Although iproniazid and niaramid are potent inhibitors of MAO, they have low levels of insecticidal activity, and do not stimulate the motor discharges in hind legs of armyworm moths. Though tranylcypromine showed a slight insecticidal activity, its action should be distinguished from those of $\mathrm{CDF}$ and DMCDF by the difference observed in symptoms and effect on motor discharges. These results do not suggest a correlation between the activity of MAO inhibition and the insecticidal potency of CDF.

\section{ACKNOWLEDGEMENT}

The authors wish to thank Dr. M. Murakami in their laboratory for his kind advice in the preparation of the manuscript.

\section{要 約}

本報ではクロルジメホルム塩酸壏 $(N-$ - 4 -chloro-Otolyl) $-N^{\prime}, N^{\prime}$-dimethylformamidine $\mathrm{HCl}, \mathrm{CDF}$ ) お よびその代謝物の殺虫性, 惹起する中毒症状および筇電 位に及ぼす影響などについて，アワヨトウ（一部カイコ ガを含む）を材料として実験を行なった。また，クロル ジメホルムおよび代謝物デスメチルクロルジメホルム (N-(4-chloro-o-tolyl)- $N^{\prime}$-methylformamidine, $\mathrm{DMCDF})$ の示すモノアミンオキシダーゼ (MAO) 阻害 作用ととれら殺虫性との相関を明らかにするため，特異 的 $\mathrm{MAO}$ 阻害刜についても同様に影響を検討した。 その
結果， $\mathrm{CDF}, \mathrm{DMCDF}$ はアワヨトウ成虫の笳肉に后復 興奮を引きおこし，殺虫性と筋電位刺激作用との間に相 関が認められた。また, CDF, DMCDF はアワヨトウ， カイコ両種の幼虫に対しては興奮的な中毒症状を惹起 し，顕著な摂食阻害性が認められた，MAO阻㔛剂は殺 虫性，筋電位刺激作用とも著しく弱く，また明確な中毒 症状も見いだせなかった。

\section{REFERENCES}

1) N. Abo-Khatwa \& R. N. Hollingworth: Life Sci. 11, 1181 (1972)

2) M. Murakami \& J. Fukami: Bull Environ. Contam. Toxicol. 11, 184 (1974)

3) S. A. Aziz \& C. O. Knowles: Nature (London) 242, 417 (1973)

4) P. W. Beeman \& F. Matsumura: Nature (London) 242, 273 (1973)

5) H. Watanabe, S. Tsuda \& J. Fukami: Pesticide Biochem. Physiol. 5, 150 (1975)

6) C. M. Wang, T. Narahashi \& J. Fukami: Pesticide Biochem. Physiol. 5, 119 (1975)

7) P. W. Beeman \& F. Matsumura: Pesticide Biochem. Physiol. 4, 325 (1974)

8) A. K. Sen Gupta \& C. O. Knowles: J. Econ. Entomol. 63, 951 (1970)

9) M. Morikawa, S. Yokoyama \& J. Fukami: Botyu-Kagaku 40, 162 (1975)

10) H. Berdereck, R. Gompper, K. Klemm \& H. Rempfer: Chem. Ber. 92, 837 (1959)

11) T. Yamasaki \& T. Narahashi: Jap. J. Appl. Entomol. Zool. 6, 293 (1962)

12) Y. Kono, D. Nagaarashi \& M. Sakai: Appl. Ent. Zool. 10, 58 (1975)

13) M. Sakai \& Y. Kono: Personal communication

14) D. Yamamoto \& J. Fukami: J. Insect Physiol. 22, 1151 (1976) 